\title{
Applicability of Tort Law for Protection of Trademark
}

\section{Mansee Teotia and Bandyopadhyay TK*}

Assistant Professor, Metallurgical and Materials Engineering RGSOIPL, IIT-Kharagpur, India

\section{Introduction}

Trademark means mark used for distinguishing goods or services of one firm, company, organization from the others. Section $2(\mathrm{zb})$ of the Indian Trade Marks Act, 1999, gives a statutory definition to the trademark as "trade mark means a mark capable of being represented graphically and which is capable of distinguishing the goods or services of one person from those of others and may include shape of goods, their packaging and combination of colours." A mark can include a device, brand, heading, label, ticket, name, signature, word, letter, numeral, shape of goods, packaging or combination of colors or any such combinations [1].

The main purpose behind giving trademark a protection is reducing consumer search cost. It indirectly protect consumer to obtain consistent quality product. A strong trademark is developed when a consumer is able to identify the source of a product or service based on the trademark as well as goodwill associated with that trademark. Creation of such reputation/goodwill requires expenditures on product quality, service, advertising etc. Therefore protection of trademark is required. With increasing competition and globalization trademark protection has gained more significance.

The use of trademarks dates from the very earliest times. Greek pottery from the earliest times has borne inscriptions. The cup handles from the Ceramicus of Athens beside the maker's name often bore real trademarks such as figures of Mercury staffs, oil jugs, bees, lions' heads [2]. Marks upon goods were in very general use among the Romans [3]. The first legislation on trademarks can be traced to England where the Bakers Marking Law, 1266 was enacted, which governed the use of stamps or pinpricks on loaves of bread. The first case of trademark infringement, Southern v How was heard as far back as 1618. Hence the concept of trademark protection as a right is since past, even when there were no codified laws existed. Violation of trademark right at that point of time was viewed as tort and applications of tort principals were done for the enforcement of rights. Tort law is designed to promote social equality and social justice. Today a relook in to principles from general tort law is required to answer questions involving liability for the indirect infringement of patents, copyrights and trademarks.

The fundamental principle of this branch of the law is alterum non ladere- to hurt nobody by words or deed. This model can be represented:

\section{Act (or omission) + Causation + Fault + Protected Interest + Damage $=$ Liability}

For establishing a tortuous action there must always exists three elements. Firstly, a legal duty on the part of defendant to act in a particular fashion. Secondly, breach of this duty by failing to conform his or her behaviour accordingly. Thirdly, injury or loss suffered by the plaintiff as a direct result of the defendant's breach.

The indirect infringement of a patent, copyright, or trademark is a statutory tort [4], liability for indirect infringement represents a subset of this more general body of tort law [5]. The law of indirect infringement has been derived from common law doctrines of joint liability for concerted action, aider and abetter liability, and liability for permitting or directing the conduct of another [6].

Indirect infringement give rise to a large number of unsettled questions like... whether a defendant would incur liability for inducing a third person to infringe a trademark if the defendant was of the belief that the trademark was invalid or the third person had a defence to trademark infringement, whether a seller of a product would be liable for trademark infringement by a third person who used the product to infringe, and whether an internet service provider would be liable trademark infringement by a user of its network.

Liability is imposed on an aider and abettor who gives substantial assistance or encouragement to another person's commission of a tort, provided the aider and abettor actually knows the other person's conduct is tortuous. Liability is also imposed on a party who induces another person to commit a tort if the inducer either knows or should know of circumstances that would make the conduct tortuous.

Under the Trademark law third party liability is imposed on fulfilment of two conditions, inducing infringement and failure of third party to take precautions.

Although liability for the direct infringement of trademarks is imposed as a strict liability basis [7], liability for indirect infringement requires showing of the third party's intent, knowledge or control with respect to the direct infringement. Particular requirements for indirect infringement is still evolving under trademarks law and depends upon case laws.

Today there has been a mass dispersal of digital technology and the widespread availability of Internet due to which there has been an unprecedented rates of trademark infringement. People residing across the globe violate exclusive rights such as copyrights and trademarks. Thus, there is recent exploitation or misuse of rights through secondary liability [8]. Secondary theories of liability in trademark law share the same origins-the common law of tort. It refers to the imposition of liability on a defendant even though that defendant did not directly commit the tort at issue.

Basic objective of the paper is to look into cases of indirect infringement and understand the specific requirement in case of indirect infringement. Hence, the present work focuses on vicarious trademarks infringement and contributory trademarks infringements which have taken birth from secondary liability of tort law.

*Corresponding author: Bandyopadhyay TK, Assistant Professor, Metallurgical and Materials Engineering, RGSOIPL, IIT-Kharagpur, India, Tel: 3222-281730; E-mail: tapas@rgsoipl.iitkgp.ernet.in

Received December 19, 2014; Accepted December 22, 2014; Published January 02, 2015

Citation: Teotia M, Bandyopadhyay TK (2015) Applicability of Tort Law for Protection of Trademark. Intel Prop Rights 3: 133. doi:10.4172/2375-4516.1000133

Copyright: $\odot 2015$ Teotia M, et al. This is an open-access article distributed under the terms of the Creative Commons Attribution License, which permits unrestricted use, distribution, and reproduction in any medium, provided the original author and source are credited. 


\section{Torts Committed by Others and its Applicability to Protect Trademark}

There are many circumstances in which a person can be held liable for an act committed by another person.

One circumstance in which liability could arise is when two or more person act in concert with each other to pursue a common end. This basis of liability is found in Restatement (Second) of Torts section 876(a), which provides: "For harm resulting to a third person from the tortuous conduct of another, one is subject to liability if he (a) does a tortuous act in concert with the other or pursuant to a common design with him, ...." [9]. 876 (a) explain that parties are set to act in concert when parties act in accordance to an agreement and cooperate with each other in a particular line of conduct to yield a particular result. Early common law based their liberties on mutual agency between them. An important aspect is that defendant conduct must itself be tortuous for defendant to be liable and defendant cannot be held liable for an act that furthers the tortuous conduct of another. 876 (a) is silent about the mental state of defendant and specifically requires the defendant and the other person to act in concert for the defendant to be held liable for the harm caused by another person.

Another circumstance in which liabilities could arise is when a person aids and abets the commission of tort. This basis of liability is found in Restatement (Second) of Torts section 876(b), which provides: "For harm resulting to a third person from the tortuous conduct of another, one is subject to liability if he ... (b) knows that the other's conduct constitutes a breach of duty and gives substantial assistance or encouragement to the other so to conduct himself, ...." [10].

On one hand where $876(\mathrm{a})$ is based on defendant acting in concert to pursue and accomplish a common result $876(\mathrm{~b})$ is based on defendant giving substantial assistance encouragement to the tortfesor for the commission of tort also where 876(a) is silent about mental state 876 (b) expressly requires that the defendant to know that other persons conduct is tortuous. The knowledge of the defendant about tortuous nature of tortfeasors conduct is crucial in determination of defendant liabilities as it form the bases for defendant's culpability and avoids holding parties liable who were not aware about their substantial assistance to the tortfeasor.

In case of aiding and abetting liability proof of knowledge is an essential. Intent and knowledge could be established by circumstantial evidence [11].

In 876(b) advice and encouragement to act tortuously has the same effect as that of participation and physical assistance.

Also defendants assistance in the form of encouragement must be a substantial factor and play substantial role in causing the tort and liability could be imposed irrespective of the fact that whether the tortfeasor is knows that the conduct constitutes a tort.

To determine whether the advice or encouragement is substantial enough for the defendant to be held liable following factors are to be considered: the nature of the act encouraged, the amount of assistance provided by the defendant, whether the defendant was present or absent at the time of the tort, the defendant's relation to the tortfeasor, and the defendant's state of mind.

Either sections of $876(\mathrm{a})$ and $876(\mathrm{~b})$ could be applicable in infringements of trademarks. 876(a) would be applicable when defendant have acted in concert with a direct infringer pursuant to an agreement to infringe a trademark and section 876(b) would be applicable where a defendant would have given substantial assistance or encouragement to a direct infringer, provided the defendant knew the direct infringer's conduct was infringing.

Inducing another person's tortious conduct is another basis for indirect liability. Restatement (Second) of Torts section 877(a) provides for liability for inducing another person to commit a tort: "For harm resulting to a third person from the tortious conduct of another, one is subject to liability if he (a) orders or induces the conduct, if he knows or should know of circumstances that would make the conduct tortious if it were his own, ...[12].

Section 877 (a) overlaps with section $876(\mathrm{~b})$, as in many cases, a defendant may both, induces another to commit a tort and also gives substantial assistance or encouragement for the commission of the tort. Section 877 (a) differs from 876 (b), as section 877 (a) requires a specific intent to cause the tortfeasor to engage in the tortuous conduct, while 876(b) the defendant's state of mind is only one of five factors that are to be considered in determining whether the defendant's assistance or encouragement was sufficient under section 876(b). Another significant difference between sections $877(\mathrm{a})$ and $876(\mathrm{~b})$ is that section 876 (b) requires the defendant to have actual knowledge that the tortfeasor's conduct constitutes a breach of duty, while section 877(a) provides for liability if the defendant's knowledge that the tortfeasor's conduct is tortious is either actual or constructive. Thus, while section 877 (a) requires a specific intent to induce tortious conduct, it requires only constructive knowledge that the tortfeasor's conduct is tortuous. Section 877(a) a person inducing would also be liable as a principal or master under the law of agency, but section 877 (a) provides an independent ground for liability.

Section 877 (a) could be applied to the infringement of trademarks, if the defendant induces the direct infringement, provided that the defendant had actual or constructive knowledge that the direct infringer's conduct was infringing.

An additional basis for liability involves a defendant's permitting a tortfeasor to use the defendant's property to commit torts. Restatement (Second) of Torts section 877(c) provides : "For harm resulting to a third person from the tortuous conduct of another, one is subject to liability if he ... (c) permits the other to act upon his premises or with his instrumentalities, knowing or having reason to know that the other is acting or will act tortiously...[13]. While section 877(c) could potentially be applicable to trademarks infringement [14], if the defendant permittes the direct infringer to use the defendant's instrumentalities provided that the defendant knew or had reason to know that the direct infringer was infringing the plaintiff's trademarks.

Another source of liability for the torts of another may be found in the Restatement (Second) of Agency. An employer is liable for torts that employees commit in the course of their employment [15].

\section{Vicarious Liability in Trademarks}

Secondary theories of liability in both trademark and copyright law share the same origins-the common law of tort and agency. Easing the reproduction of marks and by facilitating the distribution of infringing products globally, digital technology is posing threat to trademark holders.

Secondary liability comes in two forms: vicarious liability and contributory liability. Courts have recognized the availability of both common-law theories of secondary liability-contributory and vicarious in Inwood Laboratories, Inc. v. Ives Laboratories, Inc. 
[16] represents the seminal case in secondary trademark liability jurisprudence. In Ives, the Supreme Court confirmed the application of secondary liability principles to trademark law [17].

Both secondary liability theories in trademark law require an underlying act of direct infringement.

This concept of vicarious liability in trademark is similar to that of common law in which vicarious liability is established when the third party has the right and ability to control the actions of the direct infringer the third party derives a direct financial benefit from the infringement [18].

For vicarious liability under trademark law, there must exist a sufficient link between the defendant and the alleged infringer. For establishing vicarious trademark liability a strong connection need to be proved. Vicarious trademark liability relies on traditional tort law principles. Principal-agent relationship exists if the defendant and the direct infringer have an apparent or actual partnership i.e they have authority to bind one another in transactions with third parties [19]. In addition to a relationship, direct financial benefit is also required to be established for secondary liability to be attached [20].

Procter and Gamble Co. v. Haugen [21] plaintiff alleged that, defendants Mr. Haugen and the other distributor disseminated a voicemail message that identified plaintiff's products and disparaged them as having "Satanic" qualities. Proctor and Gamble also wanted Amway to be held vicariously liable for the actions of its distributor. The court analyzed that plaintiff failed to demonstrate an employment or principal-agent relationship between Amway and Haugen. Hence, the court refused to hold Amway vicariously liable for Haugen's actions. Thus, contractual relationships such as that between licensor and licensee or franchisor and franchisee are not sufficient to give rise to vicarious liability in trademark law [22]. However, in Government Employees Ins. Co. v. Google, Inc. [23] a court found that an internet search engine could be vicariously liable for the infringing acts of its advertisers. Thus, the amount of control necessary to make a defendant vicariously liable is imprecise, and subject to application depending upon the case law.

In Hard Rock Café Licensing Corp. v. Concession Services [24], the owner of the Hard Rock trademark sued a flea market owner, CSI, for both contributory and vicarious liability, contending that the owner was responsible for trademark infringement committed by a t-shirt vendor, Parvez. Parvez sold counterfeit Hard Rock t-shirts on the premises. CSI neither hired Parvez to entertain its customers nor did it take a percentage of his sales. Although infringing t-shirts brought more customers to the flea market boosted the profits of Parvez and ultimately inured to the financial benefit of the flea market owner, the court declined an attenuated link between infringement and financial benefit for liability purposes and held that only an actual profitsharing regime between the owner and the vendor or use of the direct infringer for customer/client entertainment purposes would create a sufficient nexus between acts of infringement and an owner's revenue stream to warrant vicarious liability. Hence, an obvious and direct financial benefit is required to impose vicarious liability for trademark infringement.

\section{Contributory Liability in Trademarks}

For contributory liability does not attach to every party who has knowledge of infringing activity. In addition to determining whether a "reasonably prudent person" would have perceived infringement, courts also assess the nature of the relationship between the defendant and the direct infringer [25]. Contributory infringement is based on tort law principles of enterprise liability and imputed intent. Liability in contributory trademark infringement is similar to that mentioned in Restatement (Second) of Torts sections 876(b) [26] and 877(a) [27].

In Coca-Cola Co. v. Snow Crest Beverages decision establishes the parameters of contributory liability in trademark law [28]. Courts held that knowledge necessary for contributory infringement, only permitting liability when a defendant knew or reasonably should have known that her actions would result in infringement by another. Snow Crest's "known or should have known" knowledge standard is common in other branches of tort law [29].

In addition to determining whether a "reasonably prudent person" would have perceived infringement, another parameter is the nature of the relationship between the defendant and the direct infringer [30]. Courts in Lockheed Martin Corporation v. Network Solutions [31], direct control and monitoring of the means of infringement is required for contributory trademark liability [32]. When no direct control is exercised by the defendant, contributory liability will not attach. Contributory liability does not attach to every party who has knowledge of infringing activity. In addition to determining whether a "reasonably prudent person" would have perceived infringement, a court must also assess the nature of the relationship between the defendant and the direct infringer.

\section{Conclusion}

The concept of secondary liability in trademark originates from common law of tort and agency wherein, the imposition of liability is on the defendant even though the defendant did not directly commit the tort. It is justified on economic and moral grounds. Justification on the economic ground is on the basis of shift in liability to one who can prevent further injuries and on moral grounds that one who possesses intension must be held liable for the tortuous conduct.

In many cases pertaining to trademarks infringement vicarious liability is imposed whose understanding comes from the tort law. For vicarious trademark infringement a principle agent relationship need to be established. Financial benefit is also an important aspect which must be direct. In case of Contributory trademark infringement actual or imputed knowledge is required to be established based on the concept that one who knowingly participates or furthers a tortuous act is jointly and severally liable.

\section{References}

1. Section $2(Z)(b)$.

2. Kohler. Das Recht des Markenschutzes. Wurzburg 1884; Perrot \& Chipiez, Art in Primitive Greece, Vol. I, p. 442; History of Art in Persia, p. 70 n. Birch Ancient Pottery 322, 335

3. Kohler. Das Recht des Markenschutzes

4. Carbice Corp. of Am. v. American Patents Dev. Corp., 283 U.S. 27,33 (1931) ("Infringement, whether direct or contributory, is essentially a tort, and implies invasion of some right of the patentee").

5. Sony Corp. of Am. v. Universal City Studios, Inc., 464 U.S. 417, 435 (1984) ("IV]icarious liability is imposed in virtually all areas of the law, and the concept of contributory infringement is merely a species of the broader problem of identifying the circumstances in which it is just to hold one individual accountable for the actions of another")

6. Metro-Goldwyn-Mayer Studios Inc. v. Grokster, Ltd., 125 S.Ct. 2764, 2776 (2005) ("[The] doctrines of secondary liability emerged from common law principles and are well established in the law").

7. 15 U.S.C. § 1141(1)(a) (2000) (trademarks); 17 U.S.C. $\S 501(a)$ (2000 (copyrights); 35 U.S.C. § 271(a) (2000) (patents) 
Citation: Teotia M, Bandyopadhyay TK (2015) Applicability of Tort Law for Protection of Trademark. Intel Prop Rights 3: 133. doi:10.4172/23754516.1000133

8. Mark Bartholomew, John Tehranian ; The Secret Life of Legal Doctrine: The Divergent Evolution of Secondary Liability in Trademark and Copyright Law.

9. Restatement (Second) of Torts § 876(a) (1979).

10. Restatement (Second) of Torts $\S 876(b)$ (1979).

11. Aetna Cas., Sur. Co. v. Leahey Constr. Co., 219 F.3d 519, 535 (6th Cir. 2000) ("For the purposes of establishing aiding and abetting liability, " $t$ the requisite intent and knowledge may be shown by circumstantial evidence.' ").

12. Restatement (Second) of Torts $\S 877($ a) (1979).

13. Restatement (Second) of Torts $\S 877$ (c) (1979).

14. Hard Rock Cafe Licensing Corp. v. Concession Servs., Inc., 955 F.2d 1143 (7th Cir. 1992) (t-shirts)), or a computer user might use the network of an internet service provider to infringe a copyright or trademark.

15. Restatement (second) of agency $\S 219(1)$ (1958) ("A master is subject to liability for the torts of his servants committed while acting in the scope of their employment").

16. 456 U.S. 844 (1982)

17. Id. at $853-54$

18. Fare Deals, Ltd v. World Choice Travel.com, Inc., 180 F. Supp. 2d 678, 684 (D Md. 2001); John T. Cross, Contributory and Vicarious Liability for Trademark Dilution, 80 OR. L. REV. 625, 649 (2001). According to some, a second category of vicarious liability involves joint tortfeasors, i.e., parties who act "in concert" to commit a tort and are held jointly liable for all harm caused to the victim. Cross, supra, at 635-36.

19. Hard Rock Cafe Licensing Corp. v. Concession Servs. Inc., 955 F.2d 1143,1150 (7th Cir. 1992). A principals will even risk liability for its agent's misrepresentations "upon matters which the principal might reasonably expect would be the subject of representations, provided the other party has no notice that the representations are unauthorized." Restatement (second) of agency $\S 258$.
20. Bartholomew M. Copyright, Trademark and Secondary Liability After Grokster 32 Colum. J.L. \& Arts 445 (2009)

21. Procter, Gamble Co. v. Haugen (2001) District of Utah. 158 F. Supp. 2d 1286

22. Oberlin v. Marlin American Corp., 596 F.2d 1322, 1327 (7th Cir. 1979) Min Maid Services Co. v. Maid Brigade Sys., Inc., 967 F.2d 1516, 1519 (11th Cir. 1992) Such relationships may, however, make the defendant liable for contributory trademark infringement.

23. 330 F. Supp. $2 d$ at 705

24. 955 F.2d 1143 (7th Cir. 1992).

25. Dogan, Lemley (explaining that contributory infringement requires "both an act of direct infringement ... and a special, narrowly defined relationship between the defendant and that infringement").

26. Restatement (Second) of Torts $\S 876$ (b) (1979) ("For harm resulting to a third person from the tortious conduct of another, one is subject to liability if he ... (b) knows that the other's conduct constitutes a breach of duty and gives substantial assistance or encouragement to the other so to conduct himself ....").

27. Restatement (Second) of Torts $\$ 877$ (a) (1979) ("For harm resulting to a third person from the tortious conduct of another, one is subject to liability if he (a) orders or induces the conduct, if he knows or should know of circumstances that would make the conduct tortious if it were his own, ....").

28. 64 F. Supp 980 (D. Mass. 1946). Snow-Crest was relied on by the Supreme Court in the Ives decision. Ives, 456 U.S. at 854.

29. Valentine v. LaBow, 897 A.2d 624, 633.

30. Dogan, Lemley...(explaining that contributory infringement requires "both an act of direct infringement . . . and a special, narrowly defined relationship between the defendant and that infringement").

31. 194 F.3d 980 (9th Cir. 1999).

32. SB Designs v. Reebok Int'l, Ltd., 338 F. Supp.2d 904, 913-14. 